\title{
Irrigation and Income-Poverty Alleviation: An Assessment Study of Kampe Irrigation Dam in Kogi State, Nigeria
}

\author{
Opeyemi Gbenga ${ }^{1}$, Babatunde, Raphael Olanrewaju ${ }^{1}$, Adenuga, \\ Adewale Henry ${ }^{1}$ and Olagunju, Funke Iyabo ${ }^{2}$
}

Received : 20 $0^{\text {th }}$ November, 2014 / Accepted : $31^{\text {st }}$ December, 2014

\begin{abstract}
Irrigation has been suggested to be a central key part in curbing food scarcity and alleviating poverty not only in Nigeria but also in many other developing countries. The continued dependence on rainfall in agriculture has proved incapable of sustaining the population increase. The study was conducted to assess the role of Kampe irrigation dam on farm household's income-poverty status in Kogi State, Nigeria. A two stage sampling technique was utilized for the study. Samples were drawn from irrigation beneficiaries and non-beneficiaries within the project community. A total of 140 respondents were interviewed using structured questionnaire. Also, the study used the Foster-Greer-Thorbecke (FGT) model which was used to examine the incidence, gap and severity of poverty among the sampled respondents. Logit regression model was used to identify the factors contributing to poverty state in the study area. The poverty incidence was $41 \%$ and $57 \%$ for irrigation beneficiaries and non-beneficiaries respectively. Poverty gap i.e aggregate expenditure shortfall was $6 \%$ and $21 \%$ for irrigation beneficiaries and non-beneficiaries respectively. However, poverty severity was much higher among irrigation beneficiaries (28\%) and $23 \%$ for irrigation non-beneficiaries. Farm household size, total annual farm income and total input cost all contributed to the poverty situation in the study area. Conclusion, the study agree that irrigation dam project would contribute to reducing income-poverty of irrigation farm households, from the result, the study also, based on the key research findings, this study provides recommendations on policy and interventions for making irrigated agriculture effective tool for poverty reduction program
\end{abstract}

Keywords: Irrigation, Poverty, Farm household and Assessment.

\section{INTRODUCTION}

Successful agricultural development has resulted in a significant reduction of poverty and an improvement in food security in most developing countries of Asia and Latin America. However, in many parts of Sub-Saharan Africa, despite numerous macroeconomic, political, and sectoral reforms, poverty, environmental degradation and food insecurity appear to be on the rise (Lire, 2005). Nigeria has experienced a high incidence of poverty in the last two decades and this has been largely traced to the adverse macroeconomic performance of the economy especially as dictated by the effects of negative external shocks and the adjustment reforms that were initiated in response to the shocks; succeeding governments have not been able to adequately cope with this deep-rooted problem (Olawuyi et al., 2013).

Over 70 per cent of Nigerians are now classified as poor, and 35 per cent of them live in absolute poverty. Poverty is especially severe in rural areas, where up to 80 percent of the population lives below the poverty line and social services and infrastructure are limited. The country's poor rural women and men depend on 
agriculture for food and income (Olawuyi et al., 2013). Nigeria, ranked among the 25 poorest countries in the world, started its independent nationhood with poverty level of barely $15 \%$ of its population in 1960 and is today struggling to bring it down from about $70 \%$ of its current teeming population of about 120 million and of the number of the poverty stricken people, about $73 \%$ is concentrated in the rural areas where illiteracy prevalence is high, potable water and health facilities are rarely available, road and electricity infrastructures are either unavailable or ill-managed (Ezekiel,2003). The poverty incidence in Nigeria increased from $65.6 \%$ in 1996 to $78.3 \%$ of the population in 2004. Furthermore, the distribution of extreme poverty by occupational category indicates that $67.4 \%$ of the poor in Nigeria were in agriculture (Paul et al., 2009).

Historically poverty has been viewed as lack of income, expenditure or consumption, and these money-metric approaches were used by economics for quantitative analyses to measure poverty and are still at the core of today's concept (Edward 2006) and (Majory et al., 2011). People were said to be in poverty when they are deprived of income and other resources needed to obtain the conditions of life - the diets, material goods, amenities, standards and services - that enable them to play their roles, meet their obligations and participate in the relationship and customs of their society (Majory et al.,2011). In rural development literatures, agriculture is considered one of the best vehicles to reduce rural poverty (DFID 2004).

Poverty was defined as deprivation from resources (physical, economic, social, etc.), which are needed to achieve a sustainable livelihood. Poverty is recognized to be multidimensional in its causes and manifestations; including lack of income and productive resources sufficient to ensure a sustainable livelihood; hunger and malnutrition; ill health; limited or lack of access to education and other basic services, increasing morbidity and mortality from illness, homelessness and inadequate housing, unsafe environments; social discrimination and exclusion; lack of participation in decision-making, social and cultural life (IPTRID,1999).

About 90 per cent of Nigeria's food is produced by small-scale farmers who cultivate small plots of land and depend on rainfall rather than irrigation systems. About 40 per cent of the total world food crops produced is through irrigation undertaken on only 17 percent of the total agricultural land in the world (International Programme for Technology and Research in Irrigation and Drainage, (IPTRID, 1999). This means that 60 per cent of food crops are produced with rain-fed agriculture. The marginal productivity of irrigated agriculture is therefore higher than that of rain fed agriculture. (Daniel, 2011) has therefore concluded that irrigation is the lifeline for sustained agriculture. About 70 per cent of worldwide water diverted from rivers or pumped from underground is used for irrigation. Irrigated land is far more productive than rain fed land, and the expansion of irrigation acreage over the past 30 years has contributed to gains in food production (Shadrack et al., 2004). Agricultural experts expect continuous expansion of irrigation agriculture in order to meet future food requirements in developing countries.

(Daniel, 2011) identified five key interrelated dimensions of the irrigation/poverty alleviation relationship. This includes production, income/ consumption, employment, vulnerability/ food security, and overall welfare. According to (Asayehegn, 2012), irrigation can increase employment opportunity and income. This, in turn, enables to get access to food by improving purchasing power of individuals. The existence ofv irrigation can increase income by creating more employment since it is labour intensive.

Studies that examined the link between irrigation and income-poverty status are few. An understanding of the dimensions of poverty status and its association with irrigation project 
can provide pertinent information to enable successful poverty alleviation programs. This knowledge can also inform development practitioners and policy makers to better target interventions that mitigate the severity of poverty in the rural area at large. Therefore, this study attempts to grasp the household incomepoverty condition in Kampe irrigation dam project area in Kogi State, Nigeria by focusing on the following objectives:

The overall objective of the study; irrigation and income-poverty alleviation: an assessment study of Kampe Irrigation Dam, Kogi State, Nigeria. And, the specific objective of the study is to:

(i) identifying the farm household socioeconomic characteristics in the study area,

(ii) finding out the incidence, depth and severity of poverty status among the irrigation beneficiary and non-beneficiary households, and

(iii) Identify the factors influencing poverty among the irrigation beneficiaries in the study area.

\section{RESERCH METHODS}

\section{Study area; Kampe irrigation dam project}

Kampe Dam Irrigation Project (KODIP) is located in Yagba West Local Government Area of Kogi State, Nigeria. It lies between longitudes $6^{0} 37^{\prime}$ and $6^{0} 42 \mathrm{E}$ of Greenwich and latitudes $8^{0}$ $34^{\prime}$ ' and $8^{0} 38^{\prime} \mathrm{N}$ of the Equator. The project was first conceived in 1979 while the construction works started in 1983. Kampe irrigation dam was constructed on Oyi river at Omi. It is being constructed by Niko Construction Company. The completion of the Dam at Omi River will definitely hasten irrigation projects in the country.

It involved the construction of 42 meter-dam with a water reservoir capacity of about 250 million cubic meters. The irrigation network consists of $39 \mathrm{~km}$ length of main canal and about $300 \mathrm{~km}$ length of feeder canals and complimentary drainage lines. The dam will be capable of irrigating about 4100 hectares when all the phases are completed. Given the abundant water resources in the country and its potential for increasing agricultural production in Nigeria, the Federal Government established the River Basin Development Authority (RBDA). The scheme became necessary because of the persistent too short rainy season in many states of the federation. It is against this background that Kampe irrigation project was constructed (Ibitoye, 2012).

\section{Sampling Procedure and Instrument}

The respondents for the study comprised of both irrigation dam project beneficiaries and the non-beneficiaries within same catchment area in the study area. A two stage sampling procedure was used for this study. The first stage involved the use of Stratified sampling technique; the population under study was divided into two strata; irrigation Beneficiaries and non-beneficiaries.

From each stratum, simple random sampling technique was used to collect seventy irrigation beneficiaries and seventy non-beneficiaries completing the second stage. The beneficiary list provided by the project resident head in the project site was used as the sampling frame while the list provided by the community head was used as the sampling frame for the nonbeneficiary. The data was collected using wellstructured questionnaire. The samples were drawn from the project host community.

\section{Analytical Technique}

\section{Descriptive statistics - Objective one}

Descriptive statistics was used to examine the socioeconomic characteristics of the farm households. 


\section{Poverty Indices measurement - Objective two}

The literature on aggregate measures of poverty and wellbeing is quite enormous. Many indices have been designed and developed to measure poverty and well-being. These comprise Sen index (1979); Foster-Greer-Thorbecke (FGT) poverty Index (1984); UNDP (1990), Integrated Poverty Index (IPI), Basic needs on balanced diet index, the Physical Quality of Life (PQLI) and (Morris, 1994). This study however employs the Foster, Greer, Thorbecke weighted poverty measure for quantitative poverty assessment. This class of additively decomposable poverty measure is based on income/expenditure approach.

The Foster, Greer and Thorbecke (FGT) weight-ed poverty index was used for the quantitative poverty assessment (Foster et al., 1984). The reason for this choice is due to its decomposability of the overall population into sub-groups which allows for comparison. United Nations UN (2001) noted that the most important purpose of a poverty measure is to enable poverty comparisons.

FGT allows the use of poverty indices which are the measurement of headcount ratio $\left(\mathrm{P}_{0}\right)$, depth of poverty $\left(\mathrm{P}_{1}\right)$ and severity of poverty $\left(\mathrm{P}_{2}\right)$. The measures related to the different dimension of the incidence of poverty. The three measures are based on a single formula but each index put different weight on the degree to which household or individuals falls below poverty line (Eekiel, 2003).

This approach is based on the mathematical formula which explains poverty indices anchored upon the existence of household's classification according to income or consumption expenditure.

To determine poverty profile indices, it becomes necessary to use the so called P-alpha measured analyzing poverty; its mathematical formulation is derived thus:

$$
P(\alpha)=\frac{1}{N} \sum_{i=0}^{n}\left(z-\frac{y i}{z}\right)
$$

Where $\mathrm{N}=$ the total population in the group of interest, $\mathrm{Z}=$ Poverty line, $\mathrm{n}=$ Number of individual below the poverty line, $\mathrm{Y}_{1}=$ Expenditure of income of the household in which the individual lives. $\mathrm{x}=$ the degree of concern for the depth of poverty, it takes on the value of 0,1 and 2, for poverty incidence, poverty gap and poverty severity respectively. The indices are then derived as follows:

$$
\begin{aligned}
& P(0)=\frac{1}{N} \sum_{i=0}^{n}\left(z-\frac{y i}{z}\right) \\
& P(1)=\frac{1}{N} \sum_{i=0}^{n}\left(z-\frac{y i}{z}\right) \\
& P(2)=\frac{1}{N} \sum_{i=0}^{n}\left(z-\frac{y i}{z}\right)
\end{aligned}
$$

\section{Examination of factors influencing poverty}

A logit regression model was used to analyze the factor influencing poverty status of the irrigation beneficiary respondents. These factors could have positive or negative impact on household poverty status. The model was specified as follows:

\section{Model Specification}

$\mathrm{Yi}=\mathrm{F}\left(\mathrm{X}_{1}, \mathrm{X}_{2}, \mathrm{X}_{3}, \mathrm{X}_{4}, \mathrm{X}_{5}, \mathrm{X}_{6} \mathrm{U},\right)$

Where,

$\mathrm{Y}=$ Dependent variable (Poverty status - Nonpoor $=1$, Poor $=0$ )

Explanatory variables;

$\mathrm{X}_{1}=$ Household head age (Years)

$\mathrm{X}_{2}=$ Household size (actual number)

$\mathrm{X}_{3}=$ Educational level (years)

$\mathrm{X}_{4}=$ Household farm size (hectares)

$\mathrm{X}_{5}=$ Total annual input cost (Naira)

$\mathrm{X}_{6}=$ Total annual farm income (Naira)

$\mathrm{U}=$ Error term 


\section{RESULT AND DISCUSSION}

Analysis of the socioeconomic characteristics of the farm households as shown in Table 01 indicates that irrigation farming is a male dominated enterprise in the study area. The result shows that 100 percent of the irrigation dam beneficiaries are male while only 14.3 percent of the irrigation non beneficiaries were female, indicating low participation of women in irrigation farming activities. The other reason is that when the scheme was established the major beneficiaries were migratory male farmers from the northern part of Nigeria, who left their families behind to farm under the irrigation scheme. Their families only joined them later. It is difficult for women to take such decision, this also account to their poor representation. Lastly, men felt that women could not cope with the demands of the scheme. Women only provided labour especially during harvesting and other off-farm activities to supplement household income. This agrees with (Majory et al., 2011), that there are more male headed households involved in irrigation than female.

The modal age group of the farmers falls between ages 31-40 for both irrigation farmers and non-irrigation farmers. The overall modal age group of these farmers is $31-40$ years with the lowest age group being 51-60 years of age. The results show that majority of the farmers are in their energetic years of age. The study further shows that most of the sampled farmers in the study were married $(87.9 \%)$

The study further shows that most of the irrigation farmers had large family size; about $48.6 \%$ had between 1-5 household members, $38.6 \%$ have $6-10$ household members while the percentage was $60.0 \%$ and $38.6 \%$ respectively for irrigation non-beneficiary farm households. Overall, $54.3 \%$ have family size of $1-5$ members.

With regards to education, the study shows that all of the irrigation beneficiaries had primary and below education, $71 \%$ of the irrigation nonbeneficiary respondents had post primary school formal education. Most of the farmers practice farming at subsistence level, as an overall of $70.0 \%$ had farm size of $0.1-1.0$ hectares. 27.1 $\%$ cultivated $1.1-2.0$ hectares. $68.6 \%$ of the irrigation farmers cultivated between 0.1-1.0 hectares of land.

An overall of $52.1 \%$ of the farmers had between 6-10 years farming experience, while only $12.1 \%$ had within 5 years of farming experience. Considering the fact that $76.0 \%$ of the farmers were not members of any cooperative society. All of the irrigation farmers were non-members of any cooperative society. The modal income group was $\mathrm{N} 51,000-\mathrm{N} 100,000$ with an overall per cent $55.7 \%$, irrigation beneficiary had an average annual income of $\mathrm{N} 120,782$, irrigation non-beneficiary average annual income $\mathrm{N} 88,234$ and the overall, annual income for the entire population was $\mathrm{N} 104,513$

Table 02 , showed the extent of variation in the gross margin, net farm family income as well as the structure of farm expenditures between the irrigation beneficiary and the irrigation nonbeneficiary respondents.

The level of additional net income because of irrigation access was $\$ 47,217$ naira/ hectare. The net farm income return to farm household for irrigation beneficiary was $¥ 67,760$, while that of irrigation beneficiary was $\$ 35,794$.This shows that the farm income in irrigated areas was 65.4 percent higher than the income of the irrigation non-beneficiary. The difference in farm income between these two categories of farmers could have some implications on farmer's poverty and food security status of the respondents. This agrees with a result indicating that, Irrigation is positively rated by water users with regard to income generation, well-being, and empowerment. Farmers indicate that in most cases household incomes have doubled, and in some cases even trebled (Susanne et al., 2007). The result agree with that of (Bhattarai et al.,2002), which state that Improved access to irrigation infrastructures add to additional wealth creation, and has a large impact on poverty alleviation and the improvement of livelihoods in a region. 
Table 01: Socio-economic Distribution of Respondents

\begin{tabular}{|c|c|c|c|c|c|c|}
\hline \multirow[t]{2}{*}{ Socio-economic indicators } & \multirow{2}{*}{$\begin{array}{l}\text { Beneficiary } \\
\text { household } \\
\text { Frequency }\end{array}$} & \multirow{2}{*}{\multicolumn{2}{|c|}{$\begin{array}{c}\text { Non- } \\
\text { Beneficiary } \\
\text { Frequency }\end{array}$}} & \multicolumn{3}{|c|}{ All household } \\
\hline & & & & $\%$ & Frequency & $\%$ \\
\hline \multicolumn{7}{|l|}{ Gender } \\
\hline Male & 70 & 100 & 60 & 85.7 & 124 & 92.9 \\
\hline Female & 0 & 0.0 & 10 & 14.3 & 16 & 7.1 \\
\hline \multicolumn{7}{|l|}{ Age } \\
\hline $20-30$ & 18 & 25.7 & 13 & 18.6 & 31 & 22.1 \\
\hline $31-40$ & 27 & 38.6 & 24 & 34.3 & 51 & 36.4 \\
\hline $41-50$ & 10 & 14.3 & 22 & 31.4 & 32 & 22.9 \\
\hline $51-60$ & 15 & 21.4 & 7.1 & 15.7 & 26 & 18.6 \\
\hline \multicolumn{7}{|l|}{ Marital status } \\
\hline Single & 4 & 5.7 & 13 & 18.6 & 17 & 12.1 \\
\hline Married & 66 & 94.3 & 57 & 81.4 & 123 & 87.9 \\
\hline \multicolumn{7}{|l|}{ Household size } \\
\hline $1-5$ & 34 & 48.6 & 42 & 60.0 & 76 & 54.3 \\
\hline $6-10$ & 27 & 38.6 & 27 & 38.6 & 54 & 38.5 \\
\hline $11-15$ & 4 & 5.7 & 1 & 1.4 & 5 & 3.5 \\
\hline $16-20$ & 5 & 7.1 & 0 & 0.0 & 5 & 3.5 \\
\hline \multicolumn{7}{|c|}{ Education status of household head } \\
\hline primary School and Below & 70 & 100.0 & 20 & 28 & 82 & 58.6 \\
\hline SSCE/GCE & - & - & 30 & 42.8 & 38 & 27.1 \\
\hline NCE/OND/Nursing & - & - & 17 & 24.3 & 17 & 12.1 \\
\hline HND/University & - & - & 3 & 4.3 & 3 & 2.1 \\
\hline \multicolumn{7}{|l|}{ Farm Size } \\
\hline $0.1-1.0$ & 48 & 68.6 & 49 & 70.0 & 98 & 70 \\
\hline $1.1-2.0$ & 18 & 25.7 & 21 & 30.0 & 38 & 27.1 \\
\hline$>2$ & 4 & 5.7 & 0.0 & 0.0 & 4 & 2.9 \\
\hline \multicolumn{7}{|l|}{ Experience } \\
\hline $1-5$ & 13 & 18.6 & 4 & 5.7 & 17 & 12.1 \\
\hline $6-10$ & 46 & 65.7 & 27 & 38.6 & 73 & 52.1 \\
\hline $11-15$ & 11 & 15.7 & 23 & 32.9 & 34 & 24.3 \\
\hline $16-20$ & - & - & 13 & 18.5 & 13 & 9.3 \\
\hline$>20$ & - & - & 3 & 4.3 & 3 & 2.1 \\
\hline \multicolumn{7}{|l|}{ Cooperative Membership } \\
\hline Yes & - & - & 33 & 47.1 & 33 & 23 \\
\hline No & 70 & 100 & 37 & 52.9 & 107 & 76 \\
\hline \multicolumn{7}{|l|}{ Annual income } \\
\hline $1-50,000$ & 4 & 5.7 & 5 & 7.1 & 9 & 6.43 \\
\hline $51,000-100,000$ & 29 & 41.4 & 49 & 70.0 & 78 & 55.7 \\
\hline $101,000-150,000$ & 23 & 32.9 & 10 & 14.2 & 33 & 23.6 \\
\hline $151,000-200,000$ & 9 & 12.8 & 5 & 7.1 & 14 & 10.0 \\
\hline$>200,000$ & 5 & 7.1 & 1 & 1.4 & 6 & 4.3 \\
\hline
\end{tabular}

Source: Field Survey, 2013 
Table 02: Analysis of farming profitability

\begin{tabular}{lrrr}
\hline \multicolumn{1}{c}{ Indicator } & $\begin{array}{c}\text { Irrigation } \\
\text { beneficiary } \\
\text { households }\end{array}$ & $\begin{array}{c}\text { Non-beneficiary } \\
\text { households }\end{array}$ & $\begin{array}{c}\text { Additional net } \\
\text { income }\end{array}$ \\
\hline $\begin{array}{l}\text { Gross income } \\
\text { Crops cultivated }\end{array}$ & 120,782 & 73,565 & 47,217 \\
& & & \\
Farm expenditure & 19,184 & 11,700 & \\
Fertilizer & 13,974 & - & \\
Irrigation cost & 19,864 & 26,071 & \\
Labour \& other cost & 53,022 & 37,771 & \\
Total cash expenditure & & & \\
& & & \\
Net farm income & $\mathrm{N} 67,760$ & $\mathrm{~N} 35,794$ & \\
\hline
\end{tabular}

Source: Field Survey, 2013

Table 03 shows $65.7 \%$ of the irrigation beneficiary relied on personal savings to finance their farm operation, $30.0 \%$ on credit from friends and family, and $4.3 \%$ on credit from cooperatives. None of the irrigation beneficiaries surveyed had access to credit from any commercial bank as well as agricultural banks. This is not a healthy development for small scale irrigation farmers who need credit to enable them buy all the needed farm inputs needed for farm their farm operation.

Credit is an important institutional service to finance poor farmers for input purchase, payment of labor, cover transport and storage costs and ultimately to adopt new technologies. However, some farmers have access and utilization to credit while others may not have due to problems related to repayment and down payment in order to get input from formal sources (Asayehegn, 2012). Tekana and Oladele (2011) argues that one of the most critical problems threatening the viability of irrigation farmers is the absence of credit. Access to credits need collateral mostly in the form of land right, which some smallholder farmers do not possess.

In Table 04, two kinds of analyses were simultaneously carried out to examine the impact of irrigation dam project on the poverty level of the households in the project area.
To ascertain the impact of the project on the benefitting respondents, a similar study was also conducted within the community on nonbeneficiaries in the project area.

The poverty line used for this study was calculated from the monthly MAHE of the sampled households. A poverty line of N3,866.60 based on 2013 prices, is two-thirds of the MAHE, and was expected to meet the monthly minimum basic requirements (food and non-food) of an adult in the study area. Households with a MAHE below this poverty line were classified as poor, while those with a higher MAHE were classified as being nonpoor. Based on this poverty line, $41 \%$ of the irrigation beneficiary households were classified as poor while $51 \%$ was classified as non-poor. $57 \%$ of the irrigation non-beneficiaries were classified as poor while $43 \%$ was classified as non-poor.

Analysis of the project beneficiaries and the non-beneficiaries revealed that the project has reduced poverty in the project area by $16 \%(41 \%-57 \%)$. This shows that, due to improved livelihoods as a result of the irrigation intervention, poverty was alleviated in $16 \%$ of the poor households.

The poverty gap or expenditure shortfall of 
Table 03: Distribution according to accessibility to credit

\begin{tabular}{lcc}
\hline Credit access & Frequency & Percentage \\
\hline Agriculture credit & - & - \\
Commercial bank & - & - \\
Cooperative & - & - \\
Friends and family & 21 & 30.0 \\
Personal savings & 49 & 70.0 \\
\hline
\end{tabular}

Source: Field Survey, 2013

Table 04: Poverty level within the irrigation catchment area

\begin{tabular}{lccc}
\hline \multicolumn{1}{c}{ Respondents } & Beneficiary\% & Non-beneficiary\% & \% Difference \\
\hline Poverty incidence $\left(\mathrm{P}_{\mathrm{o}}\right)$ & 41 & 57 & 16 \\
Poverty gap $\left(\mathrm{P}_{1}\right)$ & 6 & 21 & 15 \\
Poverty Severity $\left(\mathrm{P}_{2}\right)$ & 28 & 23 & 9 \\
\hline
\end{tabular}

Source: Field Survey, 2013

the poor households is $6 \%$ of the respective poverty line for irrigation beneficiaries and $21 \%$ for irrigation non-beneficiaries sampled. The results further reveal that $28 \%$ and $23 \%$ of the households for irrigation beneficiaries and non-beneficiaries respectively were severely poor. Comparison of the poverty status of the irrigation beneficiary's and non-beneficiaries reveals that the poverty level is higher by 16 $\%$ among non-beneficiary than the beneficiary respondents. The percentage of expenditure shortfall (gap) is higher among the irrigation non-beneficiaries compared to beneficiaries. However, poverty severity was higher among the irrigation beneficiary.

Even though there are more poor households among the non-beneficiaries, poverty is marginally more severe among the poor households of the irrigation households. This study agrees with the result of the study carried out by (Majory et al.,2011). Poverty index, poverty gap and the square gap index for irrigated farm families was lower than that for the nonirrigated farm families. This means there is high incidence, gap and severity of poverty among the non-irrigated farm families than among the irrigated farm families. Hussain et al., (2002) also show that incidence of chronic poverty is significantly lower in irrigated than in rain-fed settings. The empirical evidence presented so far indicates that irrigation has significant impacts on poverty. the incidence, depth and severity of poverty is substantially lower in irrigated and agriculturally developed areas compared to unirrigated and less-developed areas (Thakur et al., 2000).

In Table 05 several authors have investigated the determinants of poverty in sub-Saharan Africa Paul et al (2009). In analyzing factors that affect the poverty status of the households, a logit regression model was estimated using dummy variable $(1,0)$ for poverty status as the dependent variable. The study hypothesize that Irrigation dam can play a significant role in improving household poverty status. The independent variables were significantly related to the farm household poverty status.

Three out of six independent variables were significant; with one variables being significant at 1 percent (household farm size); while one other variables was significant at 5 percent total annual farm income). Total annual input cost was significant at 10 percent. Significant determinants of household poverty status among farm households size are $(\operatorname{Exp}(B)=2.275)$, and Total annual input cost $(\operatorname{Exp}(B)=1.646)$. 
Table 05: Determinants of household Poverty Status

\begin{tabular}{lrrrrr}
\hline \multicolumn{1}{c}{ Variables } & \multicolumn{1}{c}{ B } & \multicolumn{1}{c}{ S.E. } & \multicolumn{1}{c}{ Wald } & \multicolumn{1}{c}{ Sig. } & \multicolumn{1}{c}{ Exp(B) } \\
\hline Household head age & 0.018 & .035 & 0.273 & .602 & 0.82 \\
Household size & 0.822 & 0.245 & 11.273 & $.001^{*}$ & 2.275 \\
Household head Education level & -0.002 & 0.170 & 0.00 & .989 & 1.000 \\
Household farm size & -0.772 & 1.038 & .554 & .457 & .462 \\
Total annual input cost & 1.220 & .675 & 1.767 & $.082^{* * *}$ & 1.646 \\
Total annual farm income & .000 & .000 & 3.891 & $.0490^{* *}$ & 1.000 \\
Constant & -3.466 & 1.606 & 4.656 & .031 & .031 \\
\hline
\end{tabular}

Source: Regression results, 2014, Field survey: 2013

Dependent variable: Poverty status, *indicate significant at $1 \%$ level, ** indicate significant at $5 \%$ level, *** indicate significant at $10 \%$ level

Likelihood Ratio Chi-Square 21.566 (5)

Prediction level $82.3 \%$

Likelihood value $\quad 59.258$

\section{CONCLUSIONS}

This study suggests that Irrigation has made a significant contribution to improving poverty status in the project area. The poverty estimates were found to be relatively lower among the irrigation beneficiaries compared to non-beneficiaries. In the project community surveyed, poverty incidence has been found to be relatively lesser among irrigation beneficiaries compared to their irrigation nonbeneficiaries counterpart. Also, poverty gap was higher among the beneficiaries compared to non-beneficiaries. However, the severity of poverty was found to be higher among the irrigation beneficiaries relatively compared to non-beneficiaries.

Furthermore, regression results indicate that farm household size, total annual farm income and total annual input cost all contributed significantly to poverty alleviation in the study area among the irrigation beneficiary respondents.

\section{REFERENCE}

Asayehegn, Kinfe (2012) - Irrigation versus Rain-fed Agriculture: Driving for Households' Income Disparity, A Study from Central Tigray, Ethiopia, Agricultural Science Research Journal Vol. 2(1), pp. 20 - 29, January 2012 Available online at http://www.resjournals.com/ARJ , ISSN-L: 2026-6073 C2012 International Research Journals.
- Agricultural farm inputs at low cost or subsidy should be given to the irrigation beneficiaries to reduce production cost.

- Enlightenment program on birth control measures and it importance should be incorporated into the extension service at the farming household. This is to reduce the high family size observed in the area which could have effects on household's food security.

- In addition, efforts that could boost household's income generation should be promoted so that irrigation farm households could generate more income for the household.

- Proper enlightenment campaign should be embarked upon about the importance of irrigation dam project to the host community. This is to encourage participation. 
Bhattarai, M.; R. Sakthivadivel; and I. Hussain. 2002. Irrigation impacts on income inequality and poverty alleviation: Policy issues and options for improved management of irrigation systems. Working Paper 39. Colombo, Sri Lanka: International Water Management Institute. / irrigation impacts / irrigation and poverty, pp. 12-17, ISBN: 92-9090-476-3

Daniel Kweku BaahInkoom, (2011) - UtilisationOf Irrigation Facilities Towards Poverty Reduction In The Upper West Region Of Ghana, Journal of Sustainable Development in Africa (Volume 13, No.2, 2011) ISSN: 1520-5509. Clarion University of Pennsylvania, Clarion, Pennsylvania.

DFID (Department for International Development). (2004). Agriculture, growth and poverty reduction. [Online] Available: http://dfid-agriculture-consultation.nri.org/summaries/wp1. pdf (May14, 2007)

Edward, P. (2006). The Ethical Poverty Line: a moral quantification of absolute poverty Third World Quarterly, Vol. 27, No. 2, 2006. In International Poverty Centre (2006). What is poverty? Concepts and measures. United Nations Development Programme, Brasilia DF.

Ezekiel Oyebola Oyemomi,(2003) - An Assessment Of Poverty Reduction Strategies In Nigeria (1983 -2002), A Dissertation Submitted In Partial Fulfilment Of The Requirements For The Award Of The Doctor Of Philosophy (Management) Of The St Clements University, Nigeria.

Foster, J., J. Greer and E. Thorbecke (1984) - A Class of Decomposable Poverty measures, Econometrica 52:761-5.

Hussain, Intizar; Marikar, Fuard; Thrikawala , Sunil.(2002) - Impact assessment of irrigation infrastructure development on poverty alleviation: A case study from Sri Lanka. JBIC Research Paper No. 19. Colombo, Sri Lanka: Japan Bank for International Cooperation and International Water Management Institute. www.iwmi.cgiar.org//income

Ibitoye, Stephen Jimoh,(2012) - Survey of the Performance of Agricultural Cooperative Societies in Kogi State, Nigeria, European Scientific Journal October edition vol. 8, No.24 ISSN:18577881(Printed-ISSN1857-7431),

International Programme for Technology and Research in Irrigation and Drainage (IPTRID), (1999). - Poverty reduction and irrigated agriculture, Land and Water Development Division Food and Agriculture Organization of the United Nations Vialedelle Terme di Caracalla 00100 Rome Italy. Issues Paper No.1 January1999.

Janaiah, A., Bose, M. L. and Agarwal, A.G. 2000. Poverty and income distribution in rainfed and irrigated ecosystems: Village studies in Chhattisgarh.Economic and Political Weekly, December 30: 4664-4669.

Lire Ersado,(2005) - Small-Scale Irrigation Dams, Agricultural Production, and Health: Theory and Evidence from Ethiopia, World Bank Policy Research Working Paper 3494, January 2005, Policy Research Working Papers are available online at http://econ.worldbank.org.

Majory O. Meliko, and Stephen A. Oni (2011) - Effect of Irrigation on Poverty among Small-Scale Farmers in Limpopo Province of South Africa, www.ccsenet.org/jas Journal of Agricultural Science Vol. 3, No. 3; September 2011, pp. 1-6, E-ISSN 1916-9760 
Morris, M. O. (1994). Measuring the Condition of the World's Poor. The Physical Life Index, New York. Perganon Press.

NPC (National Population Commission) 2006, Population Census of the Federal Republic of Nigeria. Report at the National Level, National Population Commission, Abuja.

Olawuyi, S. O. and Adetunji, M. O. (2013) "Assessment of Rural Households Poverty in Nigeria: Evidence from Ogbomoso Agricultural Zone of Oyo State, Nigeria" Journal of Scientific Research \& Reports 2(1): 35-45, 2013; Article no. JSRR.2013.003 SCIENCE DOMAIN international, www.sciencedomain.org

Paul, Tahirou Abdoulaye, Patrick Kwaghe, and Amare Tegbaru.(2009) Changes in household food security and poverty status in PROSAB areas of southern Borno State, Nigeria.Promoting Sustainable Agriculture in Borno State (PROSAB).International Institute of Tropical Agriculture, Ibadan, Nigeria. $40 \mathrm{pp}$

Shadrack Mwakalila and Christine Noe (2004) - The Use of Sustainable Irrigation for Poverty Alleviation in Tanzania: The Case of Smallholder Irrigation Schemes in Igurusi, Mbarali District, Research On Poverty Alleviation, Mkuki Na Nyota Publishers Ltd, Research Report No. 04.1, Pg. 1-10.

Susanne. N, ValeskaHesse, Simone Iltgen, Japheth O. Onyando, Wilfred Onchoke, Valérie Peters, AnttiSeelaff, Daniel Taras (2007) ' Poverty Oriented Irrigation Policy in Kenya" Empirical Results and Suggestions for Reform, Discussion Paper/ISBN 978-3-88985-348-6.

Sen, A. K (1976). - Poverty An Ordinal Approach to Measurement. Econometrica 44(2): 219-231.

Tekana. S. S. and Oladele, O. I. (2011) - Impact Analysis of Taung Irrigation Scheme on Household Welfare among Farmers in North-west Province, South Africa" J Hum Ecol, 36(1):69-77 (2011).

Thakur, J.; M.L. Bose; M. Hossain; and A. Jinaiah. 2000. Rural income distribution and poverty in Bihar: Insights from village studies.Economic and Political Weekly, December, 30:46574663.

UNDP (United Nations Development Program) 1990. Human Development Report. Oxford University Press. New York. 